\title{
PERAN LEMBAGA ALTERNATIF PENYELESAIAN SENGKETA DALAM SEKTOR JASA KEUANGAN GUNA MENDUKUNG PEMBANGUNAN EKONOMI NASIONAL
}

(The Role of Alternative Dispute Resolution Institutions in the Financial Services Sector To Support National Economic Development)

\author{
Abd. Aziz Billah \\ Fakultas Hukum Universitas Indonesia \\ Jl. Prof. Mr. Djokosoetono, Kampus Universitas Indonesia, Depok, Indonesia \\ Email: thesarecha@gmail.com
}

Naskah diterima: 20 Februari 2018; revisi: 12 April 2018; disetujui: 17 April 2018

\begin{abstract}
Abstrak
Sebagai suatu tindak lanjut dalam rangka menciptakan suatu sistem penyelesaian sengketa konsumen secara sederhana, cepat, dan biaya terjangkau, maka OJK mengeluarkan Peraturan Otoritas Jasa Keuangan tentang Lembaga Alternatif Penyelesaian Sengketa (LAPS) di Sektor Jasa Keuangan. Namun perlu diketahui lebih lanjut sejauh mana peran LAPS dalam sektor jasa keuangan dalam mendukung pembangunan ekonomi nasional. Dalam penelitian ini, metode yang digunakan adalah normatif dan juga empiris dengan mengelolah data yang terkumpul dari bahan-bahan pustaka (data sekunder) dan lapangan (data primer/data dasar). Keberadaan LAPS diharapkan sebagai penunjang tugas OJK seperti yang diamanatkan dalam Undang-Undang yakni untuk melindungi kepentingan konsumen dan masyarakat. Peran LAPS dalam membantu pembangunan ekonomi nasional sangatlah penting, sebagaimana diamanatkan oleh UUD NRI tahun 1945 bahwa beban penyelenggaran pembangunan nasional bukan hanya berada di pundak pemerintah, melainkan juga ada pada masyarakat. Dengan penelitian ini diharapkan agar Lembaga Alternatif Penyelesaian Sengketa dalam bidang jasa keuangan mendapatkan perhatian khusus oleh pemerintah dengan diberikan aturan tersendiri yang tidak bertentangan dengan aturan-aturan sebelumnya.

Kata Kunci: lembaga alternatif penyelesaian sengketa (LAPS), Otoritas Jasa Keuangan (OJK), pembangunan ekonomi nasional
\end{abstract}

\begin{abstract}
As a follow-up to create a consumer dispute resolution system that is simple, fast and affordable, OJK issues the Financial Services Authority Regulation on Alternative Dispute Resolution Institutions (LAPS) in the Financial Services Sector. However, it is necessary to examine further how far the role of LAPS in financial services sector in supporting national economic development. This study used normative and also empirical methods by collecting data from library materials (secondary data) and field (primary data / basic data). LAPS role in helping national economic development is very important, as mandated by the 1945 Constitution that the burden to organize national development is not only on the government, but also on the society. Through this study, the LAPS in the financial services sector is expected to receive special attention by the government by supporting it with a special regulation which are not contradictory to the existing regulations.

Keywords: Alternative Dispute Resolution Institutions, Financial Services Authority (OJK), national economic development
\end{abstract}




\section{A. Pendahuluan}

Sejak awal kemerdekaan Indonesia pada tanggal 17 Agustus 1945 telah diletakkan dasar konstitusional yaitu UUD 1945 sebagai landasan hukum tertinggi di Negara ini. Dalam penjelasan umum UUD 1945 ditegaskan bahwa sistem pemerintahan Indonesia adalah berdasar atas Hukum (Rechsstaat), tidak berdasar atas kekuasaan belaka (Machtsstaat). Implementasi konsep Negara hukum dalam praktek penyelenggaraan Negara tersebut menempatkan hukum sebagai panglima dalam rangka mewujudkan tujuan Negara. Hukum adalah supreme yang harus ditaati oleh setiap warga Negara dan harus ditegakkan oleh Negara dalam rangka kehidupan berbangsa, bernegara, dan bermasyarakat. ${ }^{1}$

Pasal 33 Undang Undang Dasar 1945 merupakan pesan moral dan pesan budaya dalam konstitusi Republik Indonesia di bidang kehidupan ekonomi. Pasal ini bukan sekedar memberikan petunjuk tentang susunan perekonomian dan wewenang negara mengatur kegiatan perekonomian, melainkan mencerminkan cita-cita, suatu keyakinan yang dipegang teguh serta diperjuangkan secara konsisten oleh para pimpinan pemerintahan. Pesan konstitusional tersebut tampak jelas, bahwa yang dituju adalah suatu sistem ekonomi tertentu, yang bukan ekonomi kapitalistik (berdasarkan paham individualisme), namun suatu sistem ekonomi berdasar kebersamaan dan berdasar atas asas kekeluargaan. ${ }^{2}$
Bagaimanapun pembangunan ekonomi haruslah dilakukan melalui landasan hukum yang kuat. Ismail Saleh mengatakan bahwa ekonomi merupakan tulang punggung kesejahteraan rakyat, dan memang benar bahwa ilmu pengetahuan adalah tiang-tiang penopang kemajuan bangsa, namun tidak dapat disangkal bahwa hukum merupakan pranata yang pada akhirnya menentukan bagaimana kesejahteraan rakyat tersebut dapat dinikmati secara merata, bagaimana keadilan social dapat diwujudkan dalam kehidupan masyarakat, dan bagaimana kemajuan ilmu pengetahuan dan teknologi dapat membawa kemajuan bagi rakyat banyak. ${ }^{3}$

Program pembangunan ekonomi nasional juga harus dilaksanakan secara transparan dan akuntabel yang berpedoman pada prinsip demokrasi ekonomi sebagaimana diamanatkan Pancasila dan Undang-Undang Dasar Negara republik Indonesia Tahun 1945. Untuk mencapai tujuan tersebut, program pembangunan ekonomi nasional perlu didukung oleh tata kelola pemerintahan yang baik yang secara terus menerus melakukan reformasi terhadap setiap komponen dalam sistem perekonomian nasional. Salah satu komponen penting dalam sistem perekonomian nasional dimaksud adalah sistem keuangan dan seluruh kegiatan jasa keuangan yang menjalankan fungsi intermediasi bagi berbagai kegiatan produktif di dalam perekonomian sosial. ${ }^{4}$

Fungsi intermediasi yang diselenggarakan oleh berbagai lembaga jasa keuangan, dalam perkembangannya telah memberikan kontribusi

Sukardi, "Peran Penegakan Hukum dalam Pembangunan Ekonomi”, Jurnal Hukum \& Pembangunan Volume 46 Nomor 4 (2016): 435.

Herman Soewardi, Koperasi: Suatu Kumpulan Makalah, (Bandung: Ikopin, 1989), hlm. 413.

Sukardi, Op.Cit., hlm. 441.

4 M.S. Tumanggor, Pengenalan Otoritas Jasa Keuangan, Pasar Uang, Pasar Modal, dan Penanaman Modal, (Jakarta: CV. Rasterindo, 2017), hlm. 1. 
yang cukup signifikan dalam penyediaan dana untuk pembiayaan pembangunan ekonomi nasional. Terjadinya proses globalisasi dalam sistem keuangan dan pesatnya kemajuan di bidang teknologi informasi serta inovasi finansial telah menciptakan sistem keuangan yang sangat kompleks, dinamis, dan saling terkait antarsubsektor keuangan dalam hal produk maupun kelembagaan. Banyaknya permasalahan lintas sektoral di sektor jasa keuangan di dalam sistem keuangan, yang meliputi tindakan moral hazard, belum optimalnya perlindungan konsumen jasa keuangan, dan terganggunya stabilitas sistem keuangan semakin mendorong diperlukannya lembaga pengawasan di sektor jasa keuangan yang terintegrasi. ${ }^{5}$

Sebagaimana diperlukannya suatu lembaga yang melakukan pengawasan di sektor jasa keuangan, Undang-Undang Nomor 23 Tahun 1999 tentang Bank Indonesia sebagaimana telah beberapa kali diubah terakhir kali dengan Undang-Undang Nomor 6 Tahun 2009 tentang Penetapan Peraturan Pemerintah Penganti Undang-Undang Nomor 2 Tahun 2008 tentang Perubahan Kedua atas Undang-Undang Nomor 23 Tahun 1999 tentang Bank Indonesia Menjadi Undang-Undang mengamanatkan pembentukan lembaga pengawasan sektor jasa keuangan yang mencakup perbankan, asuransi, dana pensiun, sekuritas, modal ventura dan perusahaan pembiayaan, serta badan-badan lain yang menyelenggarakan pengelolaan dana masyarakat. Lembaga pengawasan sektor jasa keuangan tersebut di atas pada hakikatnya merupakan lembaga bersifat independen dalam menjalankan tugasnya dan kedudukannya berada di luar pemerintah. Lembaga ini berkewajiban menyampaikan laporan kepada Badan Pemeriksa Keuangan dan Dewan Perwakilan Rakyat. ${ }^{6}$

Semenjak OJK hadir dengan UndangUndang No. 21 Tahun 2011 tentunya kewenangan penyelesaian sengketa antara konsumen dan Lembaga Jasa Keuangan sudah menjadi tanggung jawab OJK. Dalam aktivitasnya, lembaga pengawasan sektor jasa keuangan dalam hal ini Otoritas Jasa Keuangan (OJK) menerima pengajuan dan memfasilitasi pengaduan konsumen yang dirugikan oleh pelaku di Lembaga Jasa keuangan yang terdahulu dilakukan oleh pihak Bank Indonesia (BI). Hal demikian merupakan wujud dari pelaksanaan Pasal 4 dan Pasal 29 Undang-Undang Nomor 21 Tahun 2011 tentang Otoritas Jasa Keuangan. Apabila pengaduan Konsumen tidak dapat diselesaikan oleh Bank, maka Konsumen dapat mengajukan penyelesaian sengketa melalui pengadilan atau lembaga alternatif penyelesaian sengketa (LAPS) di sektor perbankan7.

Sebelumnya di tahun 1999, Pemerintah Negara Republik Indonesia di bawah Pemerintahan Presiden BJ Habibie telah mengundangkan Undang-Undang No. 30 Tahun 1999 tentang Arbitrase dan Alternatif penyelesaian sengketa di luar forum pengadilan, dengan memberikan kemungkinan dan hak bagi para pihak yang bersengketa untuk menyelesaikan persengketaan atau perselisihan atau perbedaan pendapat di antara para pihak, dalam forum yang lebih sesuai dengan maksud

Ibid., hlm. 1-2.

Ibid., hlm. 3.

Lukmanul Hakim, "Analisis Alternatif Penyelesaian Sengketa Antara Pihak Nasabah Dengan Industri Jasa Keuangan Pada Era Otoritas Jasa Keuangan (OJK)", Jurnal Keadilan Progresif Volume 6. Nomor 2., (2015) 
para pihak. Suatu forum yang diharapkan dapat mengakomodir kepentingan para pihak yang bersengketa. ${ }^{8}$

Pada dasarnya penulisan ini didasarkan pada kedudukan Lembaga Alternatif Penyelesaian Sengketa (LAPS) dalam mendukung kinerja OJK, maka penulis memfokuskan titik kajian kepada LAPS(LembagaAlternatifPenyelesaianSengketa) dan keterkaitannya dengan pembangunan ekonomi di Indonesia. Adapun rumusan masalah dalam penulisan ini, Bagaimanakah efektifitas LAPS dalam penyelesaian sengketa pada sektor jasa keuangan guna mendukung pembangunan ekonomi nasional?

Berdasarkan pada rumusan masalah di atas, maka diharapkan tulisan ini dapat mencapai tujuan yang dimaksudkan yaitu guna mengetahui efektifitas LAPS dalam penyelesaian sengketa pada sektor jasa keuangan guna mendukung pembangunan ekonomi nasional.

\section{B. Metode Penelitian}

Penelitian ini merupakan penelitian normatif. Di mana menurut Soerjono Soekanto ${ }^{9}$ penelitian hukum normatif terdiri dari: a) Penelitian terhadap asas-asas hukum; b) Penelitian terhadap sistematika hukum; c) Penelitian terhadap taraf sinkronisasi hukum, dan e) Penelitian perbandingan hukum. Dan dikarenakan metode penelitian ini juga pendekatan dengan menggunakan metode penelitian empiris, sehingga akan didasarkan pada data yang terkumpul dari bahan-bahan pustaka (data sekunder) dan lapangan (data primer/data dasar).

\section{Pembahasan}

Undang-Undang Dasar Negara Republik Indonesia Tahun 1945 sebagai konstitusi melalui Pasal 33 ayat (4) UUD 1945, menyatakan:

"Perekonomian nasional diselenggarakan
berdasar atas demokrasi ekonomi dengan
prinsip kebersamaan, efisiensi berkeadilan,
berkelanjutan, berwawasan lingkungan,
kemandirian, serta dengan menjaga
keseimbangan kemajuan dan kesatuan
ekonomi nasional."

Makna dari prinsip kebersamaan yang tercantum pada Pasal 33 ayat (4) UUD 1945 tersebut harus dilihat dalam cakupan yang lebih luas. Masyarakat harus menyadari bahwa pemerintah mempunyai keterbatasan dana dan daya untuk melaksanakan pembangunan ekonomi karena pembangunan itu sendiri sangat kompleks, sehingga diharapkan dapat tercipta saling isi mengisi antara pemerintah dengan masyarakat untuk keberhasilan pembangunan nasional. Prinsip kebersamaan yang terkandung Pasal 33 ayat (4) UUD 1945 pada dasarnya meletakkan tanggung jawab pembangunan nasional bukan hanya di pundak pemerintah, tetapi bersama-sama di pundak pemerintah dan masyarakat. ${ }^{10}$

Kesejahteraan Masyarakat merupakan hal penting dalam tolak ukur kesuksesan pembangunan ekonomi di suatu negara. Dalam negara Indonesia pada dasarnya masyarakat sebagian besarnya merupakan konsumen dalam dunia perekonomian. Perlindungan konsumen sudah menjadi prioritas bila negara

8 Gunawan Widjaja, Alternatif Penyelesaian Sengketa, Cetakan kedua, (Jakarta: PT. RajaGrafindo Persada, 2002), hlm. 1.

$9 \quad$ Soerjono Soekanto, Pengantar Penelitian Hukum, (Jakarta: UI-Press, 2006), hlm. 51.

10 Jonker Sihombing, Peran dan Aspek Hukum dalam Pembangunan Ekonomi, (Bandung: PT Alumni, 2010), hlm. 75. 
Indonesia ingin menjadi negara yang sukses dalam pembangunan ekonomi nasional.

Kedudukan hukum dalam perlindungan konsumen guna menuntaskan tujuan negara dalam pembangunan ekonomi nasional dapat dilihat dari sudut pandang Subekti yang dalam bukunya yang berjudul "Dasar-Dasar Hukum dan Pengadilan" yang mengatakan, bahwa hukum itu mengabdi kepada tujuan negara, yang pokoknya ialah mendatangkan kemakmuran dan kebahagiaan pada rakyatnya. Dalam rangka melayani tujuan negara tersebut, hukum menyelenggarakan keadilan dan ketertiban sebagai syarat tercapainya kemakmuran dan kebahagiaan. ${ }^{11}$

Dalam interaksi antara konsumen dengan Lembaga Jasa Keuangan (LJK) yang dinamis, ditambah dengan jumlah produk dan layanan jasa keuangan yang selalu berkembang; kemungkinan terjadinya sengketa tak terhindarkan. Hal tersebut disebabkan beberapa faktor, di antaranya adalah perbedaan pemahaman antara konsumen dengan LJK mengenai suatu produk atau layanan jasa keuangan terkait. Sengketa juga dapat disebabkan kelalaian konsumen atau LJK dalam melaksanakan kewajiban dalam perjanjian terkait produk atau layanan dimaksud ${ }^{12}$. Adanya potensi sengketa tersebut perlu disikapi dengan memberikan fasilitas perlindungan yang baik terhadap konsumen pada sektor jasa keuangan.

Pemberlakuan Undang-Undang Nomor 21 Tahun 2011 tentang Otoritas Jasa Keuangan (UU
OJK) membawa harapan dan kepastian bahwa kepentingan konsumendapatterlindungi dengan baik dengan terselenggaranya kegiatan di sektor jasa keuangan yang teratur, adil, transparan, dan akuntabel serta mampu mewujudkan sistem keuangan yang tumbuh secara berkelanjutan dan stabil, dan mampu melindungi kepentingan konsumen dan masyarakat ${ }^{13}$. Berdasarkan isi UU OJK yaitu Undang-Undang Nomor 21 Tahun 2011 tentang Otoritas Jasa Keuangan, Pembentukan OJK adalah untuk melindungi kepentingan konsumen dan masyarakat. Pembentukan OJK sendiri diharapkan dapat melindungi kepentingan konsumen dan masyarakat yang menggunakan/memanfaatkan pelayanan lembaga jasa keuangan. Untuk mencapai tujuan tersebut UU OJK memberikan kewenangan edukasi, pelayanan pengaduan, sampai dengan pembelaan hukum terhadap konsumen yang dirugikan oleh lembaga jasa keuangan terhadap OJK.

Sebelum terbentuknya OJK, tugas dan wewenang di sektor jasa keuangan dipegang oleh beberapa lembaga tertentu yang berbedabeda untuk setiap jenis jasa keuangan. OJK sendiri berfungsi untuk menyelenggarakan sistem pengaturan dan pengawasan yang terintegrasi terhadap keseluruhan kegiatan di sektor jasa keuangan. ${ }^{14}$

Terkait dengan fungsi dan tujuan OJK tersebut, maka OJK mengemban tugas yang sangat penting untuk dapat mengedepankan pula perlindungan terhadap kepentingan

11 Maman Suherman, Aspek Hukum dalam Ekonomi Global, (Bogor: Ghalia Indonesia, 2005), hlm. 10.

12 Otoritas jasa Keuangan, "Lembaga Altternatif Penyelesaian Sengketa", http://www.ojk.go.id/id/kanal/edukasidan-perlindungan-konsumen/Pages/Lembaga-Alternatif-Penyelesaian-Sengketa.aspx, (diakses 12 February 2018).

13 Agus Suwandono dan Deviana Yuanitassari, “Kedudukan Lembaga Alternatif Penyelesaian Sengketa Sektor Jasa Keuangan Dalam Hukum Perlindungan Konsumen”, Jurnal Bina Mulia Hukum, Volume 1, Nomor 1 (2016) 15.

14 Ema Rahmawati dan Rai Mantili, "Penyelesaian Sengketa Melalui Lembaga Alternatif Penyeleesasian Sengketa di Sektor Jasa Keuangan”, Padjadjaran Jurnal Ilmu Hukum Volume 3 Nomor 2 (2016) 241. 
konsumen dan masyarakat. Dalam rangka melakukan upaya perlindungan terhadap konsumen dan pelaku usaha di sektor jasa keuangan, maka dikeluarkanlah peraturan pertama OJK yaitu Peraturan Otoritas Jasa Keuangan Nomor 1/POJK.07/2013 tentang Perlindungan Konsumen Sektor Jasa Keuangan (POJK Perlindungan Konsumen). Berdasarkan Pasal 2 POJK Perlindungan Konsumen. Perlindungan konsumen sektor jasa keuangan wajib menerapkan prinsip transparansi, perlakuannya yang adil, keandalan, kerahasiaan dan keamanan data/informasi konsumen, dan penanganan pengaduan serta penyelesaian sengketa konsumen secara sederhana, cepat, dan biaya terjangkau. ${ }^{15}$

Sebagai suatu tindak lanjut dalam rangka menciptakan suatu sistem penyelesaian sengketa konsumen secara sederhana, cepat, dan biaya terjangkau, maka OJK mengeluarkan Peraturan Otoritas Jasa Keuangan Nomor 1/ POJK.07/2014 tentang Lembaga Alternatif Penyelesaian Sengketa di Sektor Jasa Keuangan (POJK LAPS) mengamanatkan adanya suatu sistem penyelesaian sengketa yang terjadi di sektor jasa keuangan (khususnya antara konsumen dengan lembaga jasa keuangan), yang terdiri dari penyelesaian sengketa secara internal di lembaga jasa keuangan, penyelesaian melalui lembaga peradilan umum (pengadilan), serta melalui Lembaga Alternatif Penyelesaian
Sengketa (LAPS) dengan suatu prosedur tertentu. ${ }^{16}$

POJK Perlindungan Konsumen dan POJK LAPS pada dasarnya telah menentukan mekanisme penyelesaian pengaduan konsumen melalui 2 (dua) tahapan yaitu penyelesaian pengaduan yang dilakukan oleh lembaga jasa keuangan (internal dispute resolution) dan penyelesaian sengketa melalui lembaga peradilan atau lembaga di luar peradilan (external dispute resolution). Pasal 2 POJK LAPS menentukan bahwa pada dasarnya penyelesaian pengaduan wajib diselesaikan dahulu oleh lembaga jasa keuangan melalui unit pengaduan konsumen di tiap-tiap lembaga jasa keuangan. Penyelesaian di luar pengadilan dapat dilaksanakan apabila tidak tercapai kesepakatan penyelesaian pengaduan melalui lembaga jasa keuangan. Apabila para pihak memilih penyelesaian pengaduan sengketa dilaksanakan di luar pengadilan, maka penyelesaian pengaduan sengketa akan diselesaikan melalui Lembaga Alternatif Penyelesaian Sengketa (LAPS) yang dimuat dalam daftar lembaga Alternatif Penyelesaian Sengketa yang ditetapkan OJK. ${ }^{17}$

Pranata Penyelesaian Sengketa Alternatif pada dasarnya merupakan suatu bentuk penyelesaian sengketa di luar pengadilan, yang didasarkan pada kesepakatan para pihak yang bersengketa tersebut. Alternatif Penyelesaian Sengketa bersifat sukarela dan karenanya tidak

15 Ibid.

16 Adapun Lembaga Jasa Keuangan adalah sebagai penyedia jasa di bidang keuangan. Lembaga jasa keuangan sebagaimana dimaksud dalam Pasal 1 angka 4 UU 0JK adalah lembaga yang melaksanakan kegiatan di sektor perbankan, pasar modal, perasuarnsian, dana pensiun, lembaga pembiayaan, dan lembaga jasa keuangan lainnya., Lihat Ibid., hlm. 42.

17 Lihat Hukum Online, "Bersengketa Di Sektor Jasa Keungan? Ini Tata Cara Penyelesaiannya", http://www. hukumonline.com/berita/baca/lt570095be262e8/bersengketa-di-sektor-jasa-keuangan-ini-tata-carapenyelesaiannya, (diakses pada tanggal 18 April 2018). 
dapat dipaksakan oleh salah satu pihak kepada pihak lainnya yang bersengketa. ${ }^{18}$

Berdasarkan pada sifat keterlibatan pihak ketiga yang menangani proses Penyelesaian Sengketa Alternatif tersebut, pranata Alternatif Penyelesaian Sengketa dibedakan ke dalam: ${ }^{19}$

a. Mediasi, adalah suatu proses Penyelesaian Sengketa Alternatif di mana pihak ketiga yang dimintakan bantuannya untuk membantu proses penyelesaian sengketa bersifat pasif dan sama sekali tidak berhak atau berwenang untuk memberikan suatu masukan, terlebih lagi untuk memutuskan perselisihan terjadi. Jadi dalam mediasi, mediator hanya berfungsi sebagai penyambung lidah dari para pihak yang bersengketa.

b. Konsiliasi, adalah suatu proses Penyelesaian Sengketa Alternatif yang melibatkan seorang pihak ketiga atau lebih, dimana pihak ketiga yang diikutsertakan untuk menyelesaikan sengketa adalah seseorang yang secara profesional sudah dapat dibuktikan kehandalannya. Konsiliator dalam proses konsoliasi ini, memiliki peran yang cukup berarti, oleh karena konsiliator berkewajiban untuk menyampaikan pendapatnya mengenai duduk persoalan dari masalah atau sengketa yang dihadapi, alterrnatif cara penyelesaian sengketa yang dihadapi, bagaimana cara penyelesaian yang terbaik, apa keuntungan dan kerugian bagi para pihak, serta akibat hukumnya. Meskipun konsiliator memiliki hak dan kewenangan untuk menyampaikan pendapatnya secara terbuka dan tidak memihak kepada salah satu pihak dalam sengketa, konsiliator tidak berhak untuk membuat putusan dalam sengketa untuk dan atas nama para pihak.

c. Arbitrase, merupakan suatu bentuk penyelesaian sengketa alternatif yang melibatkan pengambilan putusan oleh satu atau lebih hakim swasta, yang disebut arbiter. Disini seorang arbiter berperan sangat aktif sebagaimana halnya seorang hakim. Dalam hal arbiter tunggal, maupun majelis arbitrase berkewajiban untuk memutuskan sengketa yang disampaikan kepadanya secara profesional, tanpa memihak, menurut kesepakatan yang telah tercapai di antara para pihak yang bersengketa pada satu sisi dan arbiter itu sendiri pada pihak lain. Arbiter haruslah independen dalam segala hal.

Keberadaan LAPS sebagai perwujudan dari perlindungan terhadap konsumen juga mempunyai prinsip-prinsip yang harus diterapkan. Prinsip-prinsip yang harus diterapkan LAPS sebagaimana diatur dalam POJK LAPS yaitu: ${ }^{20}$

a. Prinsip Aksessibilitas, yaitu LAPS memiliki skema layanan yang mudah untuk konsumen

18 Walau demikian, sebagai suatu bentuk perjanjian (Alternatif Penyelesaian Sengketa), kesepakatan yang telah dicapai oleh para pihak untuk menyelesaikan sengketa melalui forum diluar pengadilan harus ditaati oleh para pihak. Sampai seberapa sejauh kesepakatan untuk menyelesaikan sengketa di luar pengadilan ini mengikat dalam sistem hukum positif yang berlaku, ternyata tidak dapat kita temukan suatu persamaan yang berlaku secara univerrsal untuk semua aturan hukum yang berlaku, Lebih jauh dapat dilihat dalam Gunawan Widjaja, Alternatif Penyelesaian Sengketa, Op.Cit., hlm. 1-2.

19 Ibid., hlm. 2-3.

20 Peraturan Otoritas Jasa Keuangan Nomor 1/POJK.07/2014 tentang Lembaga Alternatif Penyelesaian Sengketa di Sektor Jasa Keuangan. 
retail, mengambngkan strategi komunikasi untuk meningkatkan akses konsumen, dan layanan mencakup seluruh wilayah Indonesia;

b. Prinsip Independensi, yaitu LAPS mempunyai organ pengawas, tidak ada hak veto bagi anggota (antara lain hak untuk mengganti pengurus atau mengubah peraturan LAPS), melakukan konsultasi dengan pemangku kepentingan yang relevan (seperti: asosiasi/ perhimpunan konsumen atau lembaga yang bergerak di bidang perlindungan konsumen atau asosiasi LJK dimasing-masing sektor) dalam menyusun atau mengubah peraturan sebelum menjalankannya, dan memiliki sumber daya memadai serta tidak tergantung pada LJK tertentu (adjudikator dan arbiter sangat memungkinkan untuk mencari informasi dari pihak di luar para pihak yang bersengketa, dan informasi tersebut digunakan sebagai bahan pertimbangan dalam pengambilan putusan, dengan catatan bahwa informasi tersebut wajib diinformasikan kepada para pihak);

c. Prinsip Keadilan, yaitu LAPS memiliki peraturan dalam mengambil keputusan yang mengatur, antara lain; mediator benarbenar sebagai fasilitator, ajudikator dan arbiter dilarang mengambil keputusan yang tidak diketahui para pihak dan putusan disertai dengan alasan tertulis;

d. Prinsip Efisiensi dan Efektifitas, yaitu LAPS memiliki ketentuan jangka waktu dan biaya murah, ketentuan pelaksanaan keputusan yang dikeluarkan LAPS, dan mekanisme pengawasan pelaksanaan putusan baik putusan adjudikasi, arbitrasi maupun akta kesepakatan mediasi. Dalam proses penyelesaian sengketa LAPS dapat menyediakan layanan dengan memanfaatkan teknologi informasi antara lain teleconference dan/atau video conference

Selain prinsip yang telah diatur dalam POJK LAPS, Suatu penyelesaian sengketa alternatif yang baik, setidaknya harus memenuhi prinsipprinsip sebagai berikut: ${ }^{21}$

1. Haruslah efisien dari segi waktu, harus hemat biaya;

2. Harus dapat diakses oleh para pihak, misalnya tempatnya tidak terlalu jauh;

3. Harus melindungi hak-hak dari para pihak yang bersengketa;

4. Harus dapat menghasilkan putusan yang adil dan jujur;

5. Badan atau orang yang menyelesaikan sengketa haruslah terpercaya di mata masyarakat dan di mata para pihak yang bersengketa;

6. Putusannya harus final dan mengikat;

7. Putusannya haruslah dapat dan mudah untuk dieksekusi; dan

8. Putusannya haruslah sesuai dengan perasaan keaslian dari komunitas masyarakat di mana penyelesaian sengketa alternatif tersebut.

Kedudukan LAPS Sektor Jasa Keuangan dalam penyelesaian sengketa konsumen sektor jasa keuangan ditinjau berdasarkan hukum perlindungan konsumen di Indonesia pada dasarnya merupakan lembaga penyelesaian

21 Otoritas Jasa Keuangan-Bidang Edukasi dan Perlindungan Konsumen, "LAPS Sebagai Salah Satu Alternatif Penyelesaian Pengaduan Konsumen", disampaikan pada Pembahasan Finalisasi Internal Dispute Resolution (IDR), Bandung, 11 November 2015, hlm. 10-11. 
sengketa yang memiliki karakterisk khusus. Karakteristik tersebut karena LAPS Sektor Jasa Keuangan khusus ditujukan bagi konsumen di sektor jasa keuangan yakni konsumen dalam pengertian luas bukan hanya konsumen akhir sebagaimana dimaksud dalam Undang-Undang Nomor 8 Tahun 1999 tentang Perlindungan Konsumen yang lebih lanjut dikenal dengan UUPK. Ketentuan-ketentuan dalam UUPK dalam hal ini tidak bisa mutlak bisa diterapkan dalam penyelesaian sengketa konsumen sektor jasa keuangan melalui LAPS Sektor Jasa Keuangan. ${ }^{22}$

Untuk dapat masuk dalam daftar LAPS di Sektor Jasa Keuangan, terdapat tahapan penilaian yang menjadi acuan kelayakan, sebelum diumumkan terdaftar sebagai LAPS yang diakui oleh OJK. Adapun penilaian tersebut:23

a. Analisis pendahuluan yang dilakukan dengan tahapan sebagai berikut:

1) Permintaan dokumen dan/atau informasi kepada LAPS;

2) Verifikasi kepada LAPS (jika diperlukan);

3) Pengolahan dokumen dan atau informasi LAPS; dan

4) Perumusan hasil analisis atas dokumen dan atau informasi LAPS;

5) Pengujian pemenuhan syarat-syarat LAPS.

Pengujian pemenuhan syarat-syarat LAPS dilakukan oleh Tim Penguji LAPS yang terdiri dari tujuh orang yang berasal dari internal dan eksternal OJK, berdasarkan pembobotan dan skala penilaian sebagaimana diatur dalam Surat Edaran OJK mengenai Pedoman
Penilaian Lembaga Alternatif Peyelesaian Sengketa di Sektor Jasa Keuangan.

b. Penetapan Hasil Penilaian Hasil penilaian LAPS diklasifikasikan menjadi dua, yaitu:

1) Memenuhi syarat apabila memperoleh nilai paling sedikit 75 (tujuh puluh lima) dan tidak terdapat nilai nol pada komponen syarat LAPS; atau

2) Belum memenuhi syarat apabila memperoleh nilai kurang dari 75 (tujuh puluh lima) atau terdapat nilai nol pada komponen syarat LAPS.

Adanya ketentuan keberlakuan POJK tentang LAPS dan dengan didasarkan oleh itu, maka OJK telah memperbaharui Daftar Lembaga Alternatif Penyelesaian Sengketa di Sektor Jasa Keuangan melalui Pengumuman Nomor Peng- 2/D.07/2016 tentang Daftar Lembaga Alternatif Penyelesaian Sengketa Di Sektor Jasa Keuangan berdasarkan Keputusan Nomor Kep6/D.07/2016 tanggal 20 Desember 2016. Daftar Lembaga Alternatif Penyelesaian Sengketa di Sektor Jasa Keuangan tersebut adalah: ${ }^{24}$
a. Badan Mediasi dan Arbitrase Asuransi Indonesia (BMAI)
b. Badan Arbitrase Pasar Modal Indonesia (BAPMI)
c. Badan Mediasi Dana Pensiun (BMDP)
d. Lembaga Alternatif Penyelesaian Sengketa Perbankan Indonesia (LAPSPI)
e. Badan Arbitrase dan Mediasi Perusahaan Penjaminan Indonesia (BAMPPI)


f. Badan Mediasi Pembiayaan, Pengadaian dan Ventura Indonesia (BMPPVI)

Bagaimanapun, kehadiran LAPS tersebut telah membawa aspek positif dalam perlindungan terhadap konsumen di sektor jasa keuangan dengan harapan terciptanya hubungan yang kondusif antara konsumen dengan pelaku usaha jasa keuangan. Pada akhirnya, kondisi tersebut dapat meningkatkan kinerja sektor jasa keungan dalam mendukung pembangunan sektor ekonomi di Indonesia.

Seperti halnya salah satu LAPS, sebagai contoh LAPS dalam sektor jasa keuangan yang telah ditetapkan OJK yaitu Badan Mediasi dan Arbitrase Asuransi Indonesia (BMAI) dalam realisasi hasil mediasi dan ajudikasi tahun 2016 terdapat banyak sengketa yang di tangani oleh BMAl dari tahun 2006 sampai dengan tahun 2016. Adapun rincian hasil mediasi dan ajudikasi BMAl tahun 2016 adalah sebagai berikut; Asuransi Jiwa dengan total 215 sengketa, Asuransi Sosial dengan total 3 sengketa dan asuransi umum dengan total 287 sengketa. ${ }^{25}$ Hal ini dapat menjadi tinjauan melihat seberapa banyak sengketa yang dipercayakan untuk diselesaikan pada BMAI sebagai LAPS dalam sektor jasa keuangan.

Lebih lanjut dalam proses penyelesaian sengketa pada BMAl ini, terdapat 3 tahapan yaitu: ${ }^{26}$

a. Tahap 1 (Mediasi): Permohonan Penyelesaian Sengketa Klaim Asuransi yang diterima BMAl akan ditangani oleh mediator yang akan berupaya agar Tertanggung atau pemegang Polis dan Penanggung
(Perusahaan Asuransi) dapat mencapai kesepakatan untuk menyelesaiakan sengketa secara damai dan wajar bagi kedua belah pihak. Mediator akan bertindak sebagai penengah antara Tertanggung atau Pemegang Polis (Pemohon) dan Penanggung atau Perusahaan Asuransi (Termohon).

b. Tahap 2 (Ajudikasi): Bila sengketa klaim (tuntutan ganti rugi atau manfaat) tidak dapat diselesaikan melalui Mediasi (Tahap 1), maka pihak pemohon dapat mengajukan permohonan kepada Ketua BMAl agar sengketanya dapat diselesaikan melalui proses Ajudikasi. Sengketa akan diputuskan oleh Majelis Ajudikasi yang ditujukan oleh BMAI.

c. Tahap 3 (Arbitrase): Atas sengketa klaim yang tidak dapat diselesaikan pada proses Mediasi atau Ajudikasi dan yang nilai sengketanya melebihi batas nilai tuntutan ganti rugi dilakukan proses arbitrase. Sengketa klaim akan diperiksa dan diadili oleh arbiter tunggal atau majelis arbitrase. Keputusan arbitrase bersifat final dan mengikat para pihak dan tidak dapat dimintakan banding, kasasi atau upaya hukum lainnya.

Pada tahap 3 (tiga) dapat disimpulkan bahwa keputusan arbitrase harus dilaksanakan karena bersifat final. Sehingga sengketa yang sampai pada tahap 3 (tiga) tidak dapat lagi diajukan dalam bentuk apapun.

Dengan demikian, adanya lembaga alternatif penyelesaian sengketa di sektor jasa keuangan diharapkan dapat mewujudkanadanya kepastian bagi konsumen dan lembaga jasa keuangan atas

25 Badan Mediasi Dan Arbitrase Asuransi Indonesia, "Realisasi Hasil Mediasi Dan Ajudikasi Tahun 2016”, http:// bmai.or.id/index.php?option=com_content\&view=article\&id=238\&Itemid=725, (diakses 5 April 2018).

26 Ibid. 
sengketa yang timbul. Putusan yang dihasilkan dalam penyelesaian sengketa melalui lembaga alternatif penyelesaian sengketa di sektor jasa keuangan dapat dijadikan oleh konsumen sebagai bahan pembelajaran mengenai hak dan kewajibannya. Sedangkan bagi lembaga jasa keuangan, putusan dimaksud dapat digunakan untuk menyempurnakan produk dan jenis layanan yang telah diterbitkan. Lembaga jasa keuangan juga akan mampu mengembangkan produk dan layanannya dengan menyesuaikan pada kemampuan dan kebutuhan konsumen. ${ }^{27}$ Oleh karena itu keberadaan LAPS dalam Sektor Jasa Keuangan sangatlah penting dalam menyelesaikan sengketa-sengketa pada sektor Jasa keuangan guna membantu pembangunan ekonomi nasional.

\section{Penutup}

Berdasarkan penjelasan diatas, maka dapat disimpulkan bahwa hadirnya lembaga Otoritas Jasa Keuangan di Indonesia diharapkan dapat memaksimalkan dengan baik aktifitas ekonomi yang ada, salah satunya dengan mewujudkan perlindungan kepada konsumen. Pembentukan OJK dimaksudkan pula untuk mewujudkan perekonomian nasional yang mampu tumbuh secara berkelanjutan dan stabil. Oleh karenanya, OJK menerbitkan POJK terkait dengan Perlindungan Konsumen Sektor Jasa Keuangan dan tentang Lembaga Alternatif Penyelesaian Sengketa (LAPS). Keberadaan LAPS diharapkan sebagai penunjang tugas OJK seperti yang diamanatkan dalam UU OJK bahwa OJK diharapkan mampu melindungi kepentingan konsumen dan masyarakat. Sesungguhnya peran
LAPS dalam membantu pembangunan ekonomi nasional sangatlah penting mengingat bahwa UUD 1945 mengamanatkan agar pembangunan nasional bukan hanya dipundak pemerintah, melainkan bersama-sama di pundak pemerintah dan masyarakat. Oleh karena untuk memastikan jalannya kebersamaan itu, haruslah ada lembaga alternatif sebagai penyeimbang yang hadir dengan prinsip-prinsip yang tidak berpihak pada pemerintah saja. Dengan adanya lembaga alternatif penyelesaian sengketa di sektor jasa keuangan, maka akan terwujud adanya kepastian bagi konsumen dan lembaga jasa keuangan atas sengketa yang timbul.

Tidak lupa juga saran yang penulis berikan yaitu: agar kiranya Lembaga Alternatif Penyelesaian Sengketa dalam bidang jasa keuangan mendapatkan perhatian khusus oleh pemerintah dengan diberikan aturan tersendiri yang tidak bertentangan dengan aturan-aturan sebelumnya. Metode penyelesaian yang begitu terjangkau oleh konsumen dalam hal ini masyarakat menyebebkan peran LAPS di masa yang akan datang menjadi sangat penting oleh karenanya sangat perlu diperhatikan keberadaannya baik oleh pemerintah maupun masyarakat.

\section{Daftar Pustaka}

\section{Buku}

Darmodiharjo, Darji \& Shidarta, Pokok-Pokok Filsafat Hukum, Apa dan Bagaimana Filsafat Hukum Indonesia, (Jakarta: Gramedia Pustaka Utama, 1995).

Siagian, Sondang, Administrasi Pembangunan, Konsep, Dimensi, dan Strateghinya, Cetakan ke4, (Jakarta: Bumi Aksara, 2005).

27 Otoritas Jasa Keuangan, "FAQ atas Peraturan OJK tentang Lembaga Alternatif Penyelesaian Sengketa (LAPS) di Sektor Jasa Keuangan, Nomor 13”, www.ojk.go.id/Files/regulasi/ojk/pojk/faq-pojk-laps.pdf, (diakses 19 february 2018). 
Sihombing, Jonker, Peran dan Aspek Hukum dalam Pembangunan Ekonomi, (Bandung: PT Alumni, 2010)

Soekanto, Soerjono, Pengantar Penelitian Hukum, (Jakarta: UI-Press, 2006).

Soewardi, Herman, Koperasi: Suatu Kumpulan Makalah, (Bandung: Ikopin, 1989).

Suherman, Maman, Aspek Hukum dalam Ekonomi Global, (Bogor: Ghalia Indonesia, 2005).

Tumanggor, M.S., Pengenalan Otoritas Jasa Keuangan, Pasar Uang, Pasar Modal, dan Penanaman Modal, (Jakarta: CV. Rasterindo, 2017).

Widjaja, Gunawan, Alternatif Penyelesaian Sengketa, Cetakan kedua, (Jakarta: PT. RajaGrafindo Persada, 2002)

\section{Makalah/Artikel/Prosiding/Hasil Penelitian}

Agus Suwandono dan Deviana Yuanitassari, "Kedudukan Lembaga Alternatif Penyelesaian Sengketa Sektor Jasa Keuangan Dalam Hukum Perlindungan Konsumen", Jurnal Bina Mulia Hukum, Volume 1, Nomor 1 (2016)

Elli Ruslina, "Makna Pasal 33 Undang-Undang Dasar 1945 dalam Pembangunan Hukum Ekonomi Indonesia", Jurnal Konstitusi Volume 9. Nomor 1 (2012).

Ema Rahmawati dan Rai Mantili, "Penyelesaian Sengketa Melalui Lembaga Alternatif Penyeleesasian Sengketa di Sektor Jasa Keuangan", Padjadjaran Jurnal IImu Hukum Volume 3 Nomor 2 (2016).

Lukmanul Hakim, "Analisis Alternatif Penyelesaian Sengketa Antara Pihak Nasabah Dengan Industri Jasa Keuangan Pada Era Otoritas Jasa Keuangan (OJK)", Jurnal Keadilan Progresif Volume 6 Nomor 2 (2015).

Otoritas Jasa Keuangan Bidang Edukasi dan Perlindungan Konsumen, "LAPS Sebagai Salah Satu Alternatif Penyelesaian Pengaduan Konsumen", (disampaikan pada Pembahasan Finalisasi Internal Dispute Resolution (IDR), Bandung, 11 November 2015).
Otoritas Jasa Keuangan, "Pengumuman Nomor Peng- 2/D.07/2016 tentang Daftar Lembaga Alternatif Penyelesaian Sengketa Di Sektor Jasa Keuangan".

Sukardi, "Peran Penegakan Hukum dalam Pembangunan Ekonomi", Jurnal Hukum \& Pembangunan Volume 46 Nomor 4 (2016).

\section{Internet}

Badan Mediasi Dan Arbitrase Asuransi Indonesia, "Realisasi Hasil Mediasi Dan Ajudikasi Tahun 2016", http://bmai.or.id/index. php?option $=$ com_content $\&$ view $=$ article $\& i d=23$ 8\&ltemid=725, (diakses 5 April 2018)

Otoritas jasa Keuangan, "Lembaga Altternatif Penyelesaian Sengketa", http://www.ojk.go.id/ id/kanal/edukasi-dan-perlindungan-konsumen/ Pages/Lembaga-Alternatif-PenyelesaianSengketa.aspx, (diakses 12 February 2018)

Otoritas Jasa Keuangan, "FAQ atas Peraturan OJK tentang Lembaga Alternatif Penyelesaian Sengketa (LAPS) di Sektor Jasa Keuangan, Nomor 13", www.ojk.go.id/Files/regulasi/ojk/pojk/faqpojk-laps.pdf, (diakses 19 Februari 2018).

Hukum Online, "Bersengketa Di Sektor Jasa Keungan? Ini Tata Cara Penyelesaiannya", http://www.hukumonline.com/berita/baca/ It570095be262e8/bersengketa-di-sektorjasa-keuangan-ini-tata-cara-penyelesaiannya, (diakses 18 April 2018).

\section{Peraturan}

Undang-Undang Dasar Negara Republik Indonesia Tahun 1945.

Undang-Undang Nomor 21 Tahun 2011 tentang Otoritas Jasa Keuangan.

Peraturan Otoritas Jasa Keuangan Nomor 1/ POJK.07/2014 tentang Lembaga Alternatif Penyelesaian Sengketa di Sektor Jasa Keuangan.

Peraturan Otoritas Jasa Keuangan Nomor 1/ POJK.07/2013 tentang Perlindungan Konsumen Sektor Jasa keuangan. 